\title{
Bajau laut boat-building in Semporna
}

Bajau laut boat-building in Semporna

La construcción naval de los Bajau Laut en Semporna

\section{Clifford Sather}

\section{(2) OpenEdition}

\section{Journals}

Electronic version

URL: https://journals.openedition.org/tc/288

DOI: $10.4000 /$ tc. 288

ISSN: 1952-420X

\section{Publisher}

Éditions de l'EHESS

\section{Printed version}

Date of publication: 1 January 2001

Number of pages: 177-198

ISSN: 0248-6016

\section{Electronic reference}

Clifford Sather, "Bajau laut boat-building in Semporna", Techniques \& Culture [Online], 35-36 | 2001,

Online since 07 September 2012, connection on 29 September 2022. URL: http://

journals.openedition.org/tc/288; DOI: https://doi.org/10.4000/tc.288

This text was automatically generated on 29 September 2022.

All rights reserved 


\title{
Bajau laut boat-building in Semporna
}

\author{
Bajau laut boat-building in Semporna \\ La construcción naval de los Bajau Laut en Semporna
}

Clifford Sather

1 The Semporna district lies at the extreme southeastern corner of the Malaysian State of Sabah (fig. 1). It is comprised of a narrow, mountainous peninsula projecting from the east Borneo coast, bordered by scores of islands. High volcanic peaks (450-575 metres) form the central spine of the peninsula, representing, geologically speaking, a continuation of the Sulu tectonic arc that runs eastward from the tip of the peninsula through the Sulu Archipelago of the Philippines. These peaks fall away steeply on the north to the Sulu Sea and on the south to the Celebes Sea, and, moving eastward, they gradually decrease in height, ending in a series of steep hills. Offshore, the arc continues though a series of high volcanic islands, and, to the north, paralleling the peninsula coastline, a group of larger islands. Mount Sirongal, rising from the largest of these islands, is, at 486 metres, the highest offshore point in the district. Interspersed around these high islands are more numerous low islands and, surrounding these, and bordering parts of the peninsula coastline, are fringing reefs and extensive formations of coral terraces and shoals, the traditional fishing grounds of a substantial population of Sama-speaking peoples, including once nomadic groups of boat-dwelling Bajau Laut. 


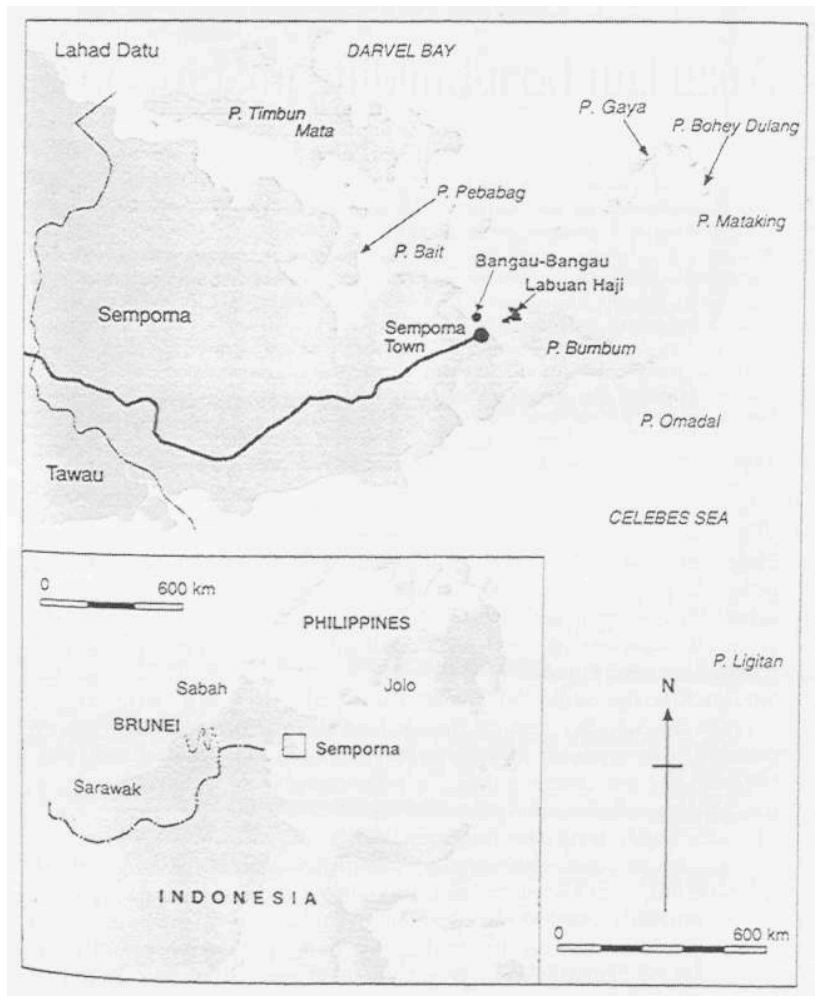

FIgURE 1. SEMPORNA DISTRICT, SHOWINg LOCATION OF THE BAJAU LAUT SETTLEMENTS OF BANgAUBANGAU AND LABUAN HAJI

Because of the presence of these rich coral formations, and the location of the district at the juncture of the Sulu Archipelago and the eastern Borneo coast, Semporna has long been a home to maritime trading and seafaring peoples. In 1990 the district population was 91,989 (Malaysia, Department of Statistics, 1993 : 11). Sama-speakers make up over 70 per cent of this total (Sather $1997: 24-25$ ). More generally, the Sama comprise what is arguably the most widely dispersed ethnolinguistic group indigenous to Insular Southeast Asia. Altogether, Sama-speakers inhabit a vast maritime area of some 3.25 million square kilometres, extending from eastern Palawan, Samar, and coastal Mindanao on the north, through the Sulu Archipelago of the Philippines, to the eastern coast of Borneo, and southward through the Straits of Makassar to Sulawesi and from there, over large parts of eastern Indonesia (see Sather $1993: 30,1997: 2-5$ ). In Sabah, Sama-speakers are generally known as Bajau, a term of probable Malay origin, but one that many Sama are now coming to adopt for themselves.

In the Semporna district, small sea-nomadic communities historically formed an integral part of the local Bajau population. Known as Bajau Laut, or locally, to other Sama speakers, as Sama Pala'au, these people identify themselves as Sama Dilaut or Sama Mandelaut, names meaning literally, the "Sea " or "Maritime Sama ». In addition, they also call themselves, more simply, a'a dilaut, « sea people », in contrast to the a'a déa, «inland people », by which they refer to all others who live permanently ashore, chiefly, in the Semporna district, people living in settled strand or island villages (Sather 1997: 5-8). From 1964 through the early 1980s, the Sama Dilaut comprised roughly 4 to 5 per cent of the total Sama-speaking population of Semporna. When I began my fieldwork in 1964, the Bajau Laut population of the district was 660 and was divided between two settlements, Labuan Haji and Bangau-Bangau, each 
located, facing the other, at opposite sides of a narrow strait separating the eastern tip of the Semporna peninsula from Bumbum Island.

Starting in 1954, the Semporna Bajau Laut began to abandon boat-dwelling. By the time I began my research in 1964, most families lived, for at least part of each year, in wooden pile houses built over the sea. Households were generally large and often comprised more than one family unit (Sather 1978, 1997: 134-87). From these two villages, individual families regularly dispersed in their boats, singly or in small fleets, on extended fishing voyages lasting from one or two days to several weeks at a time (Sather 1985).

5 Since 1965, the Bajau Laut population has grown steadily and today stands at well over 3,000. Not only have the Semporna Bajau Laut abandoned boat-dwelling, but, in recent years, many have also left fishing and make their living today by other occupations, mainly wage labor, marketing, and petty trade. In addition, the former village of Bangau-Bangau is now divided, for administrative purposes, into two large settlements, Kampungs Bangau-Bangau and Sri Kanangan. Each has its own headman and Village Development Committee and today both are being progressively drawn into the urban boundaries of Semporna town, the administrative and commercial center of the district. Although the Bajau Laut remain in the majority, both villages include nonBajau Laut households, as well as a small number of shops and other commercial structures, a community mosque and primary school (Sather $1997: 83-87$ ). Since 1980, a fourth village has been established adjacent to Bangau-Bangau and Sri Kanangan. This is called Kampung Halo and its population is made up largely of Sama Dilaut migrants or « refugees» (pelarian), chiefly from the Tawitawi Island Group in southern Sulu (see Sather 1997 : 83ff). The local Bajau Laut speak a dialect of Southern Sama (Walton and Moody 1984 : 115-22), which, although identifiably distinct, is readily intelligible to most other Sama-speakers in Semporna, including the Sama Kubang, the single most populous group in the district.

The Bajau Laut in Semporna, and throughout the Sulu Archipelago, have long been involved in a commoditized economy, procuring sea products such as dried fish, tripang, and pearls hell -not for their own subsistence- but for export and interregional trade. Until the district was brought under Chartered Company rule, shortly before the turn of the twentieth century, the Semporna region was part of the political and economic sphere of the Sulu Sultanate (see Sather 1997: 37ff; Kiefer 1972). The economic basis of the sultanate was a redistributive trading network in which differently adapted groups, many of them Sama-speaking, supplied products of trade for export markets beyond the Archipelago. The status of the Bajau Laut was defined primarily by their boat-dwelling way of life and by their lack of independent claim to rights in land ashore. In effect, these attributes defined them as a client population, subject, in varying degrees, to the authority of land-based leaders having recognized rights over the areas of strand, islands, and intertidal shallows in which local groups of sea people established their mooring sites, collected freshwater, or located the graves of their dead in shore-side cemeteries. In return for protection and the use of these sites, land-based leaders enjoyed a privileged trading relationship in regard to their boat-dwelling clients. It was traditionally through these relationships that sea products entered into the redistributive economy, moving generally upward and inward, toward Jolo, the principal port of trade and seat of state power. However, by the second half of the nineteenth century, the power of the Sulu Sultanate was in 
decline as a result of increasing Spanish military intervention in the Sulu Archipelago, the growing presence of Chinese traders, monetization, and the reorientation of maritime trade, away from Sulu, and through the then newly developing colonial ports of Sandakan, Singapore, and Hong Kong (Sather $1997: 60 \mathrm{ff}$ ).

In addition to political clientage and traditional procurement relations, ties between different Sama groups in Semporna tended to be characterized by local exchange-based specializations. Thus, the Bajau Laut depended upon the exchange of fish and other sea products to obtain rice and cassava (Manihot spp) from neighboring land-based groups. Others, in particular the Sama Banaran, supplied them with boat-caulking resin (butik) and manufactured sapau mats which the Bajau Laut traditionally used to roof the living quarters of their boats ${ }^{2}$. In 1964-65, this trade in mats still continued, but was conducted by means of cash. Still other groups produced earthenware pottery, including water jars, cooking pots, and portable hearths (lappohan), the latter carried aboard boats and used for cooking at sea. Sama Kubang communities present around the northeastern shore of Bumbum Island historically specialized in a variety of craft industries, including smithing, woodworking, and the production of tortoiseshell combs and pendants. Here, in addition, a number of village men made a specialized living as boatwrights. In 1965 the finest lepa were produced by Sama Kubang boatbuilders at Kampungs Kambimbangan, Nusalalung, and other Sama Kubang villages on Bumbum Island. These boats were built specifically for the Bajau Laut, not only for those living in Semporna, but for others as well. Thus, Sama Dilaut from Sitangkai, in the adjacent Sibutu Island Group of Sulu, regularly traveled to the district to commission Sama Kubang builders to construct lepa, returning at a pre-arranged date to take possession of the completed boat. In smaller numbers, other Sama Dilaut came from Bongao and Sanga-Sanga, and from as far east in the Sulu Archipelago as the Siasi Island Group. The Semporna Bajau Laut also built boats, chiefly for their own use, but also, on a much more limited scale, for sale. In addition, Sitangkai families, down through the early 1970s, traveled to Semporna, where they stayed with relatives in Bangau-Bangau or Labuan Haji, or lived in their boats, remaining long enough to purchase materials and complete a lepa, before returning home across the Philippine border. Sitangkai itself, and the rest of the Sibutu Island Group, consist of low coralline islands without boat-building timber, and the other southern island groups of Sulu are also, very largely, timber deficient.

By contrast, Semporna was historically an area in which lowland hardwoods, ideal for boat construction, were relatively plentiful. In the past, trees were felled, mainly in the coastal lowlands, and, using high tides, the logs were floated to the sea by way of small rivers and estuarine streams. They were then towed to the village or boat mooring site where the feller worked them into boat sections and planks. Because of the availability of wood, not only the Bajau Laut, but also communities of shore-dwelling Sama, historically produced lepa and, indeed, other kinds of vessels for trade. Today, these lowland forests are gone, and wood, available through local sawmills, has become increasingly expensive, resulting in the appearance of new types of boats and the disappearance, during the last two decades, of the lepa.

However, in 1964-65, the chief boats used by the Bajau Laut were the lepa, which served as the primary fishing boat, and the boggo', a much smaller, ancillary dug-out ${ }^{3}$. Lepa and boggo' have different functions. The boggo' is used exclusively inshore, or over shallow water, while the lepa serves as the main fishing vessel and family home during 
sea voyages. According to village informants, the lepa was first made for trade by Sama Kubang boatwrights and was adopted by the Bajau Laut, apparently replacing earlier outrigger boats. Its introduction may have been as recent as the beginning of the twentieth century, although this is not certain. However, photographs taken in Semporna in the 1910s and early 1920s show only small outrigger vessels (e.g., see Cook $1924: 120)$.

\section{The boat construction process} Bangau and a second one was begun. Most of the remaining boats in use, about 50 at the time, underwent minor repairs during these months. There was no time when work on a boat was not being done in some part of the village or on the nearby shore close to the foot of the village bridge. Because intervals of time must be given over to other activities, the villagers say that a lepa cannot be built in less than three or four months, and some are known to have taken well over a year to complete. I returned to BangauBangau for shorter periods of fieldwork in 1974 and 1979. Lepa were still being built, but by 1979 , commercial logging had almost entirely deforested the district and it was becoming increasingly difficult to obtain wood for the solid keel and bow sections, and a new type of boat, the pombot, had appeared.

Before beginning to construct a lepa, the builder must decide upon its length and other dimensions. These decisions are influenced by the availability of wood, particularly for the bow, stern, and keel sections. If wood must be purchased, they also depend on the amount of money that the builder is prepared to spend. In 1964-65, lepa varied greatly in length from 7 to 12 metres (the average was 8.5 metres) and from 1.5 to 1.9 metres beam. Beam is relatively constant, but length is notably variable. The lepa draft has an average of some 0.6 metre.

The basic tool kit used in boat construction consists of an adze (patuk) with a detachable steel blade that can be rotated for different cutting angles, a knife (bari'), a wooden mallet (palu), and a brace and bit. In addition, a handsaw may be used, particularly for cutting planks, and a plane for leveling. Skate or shark skin is used as sandpaper. Fire is frequently employed to hollow and widen the keel section.

Construction begins by first shaping the keel section (teddas), which is fashioned from a single piece of wood (photo 1), and by joining it with the bow and stern sections. The latter are called tuja' and tuja' buli', respectively, and consist of identical left and right sections. Once these have been joined to the keel, the builder and his assistants begin to construct the hull, joining first the left and right side strakes, or pangahapit (photo 2). The bow, stern, and strakes are then locked in place by a pair of long, carefully fitted side pieces, called the jungal, which run the entire length of the boat, ending forward in a projecting bowsprit and aft in a small stem projection (fig. 2). Next, sideboards are added, beginning with the bengkol. This is fitted above the strake and to the jungal on the side, to form the gunwale. The top edge of each board is marked at intervals and drilled with the brace and bit. Boards are made from planks and are carved to shape using an adze, and are then curved by bending and fitted edge to edge with wooden dowels (pasok) made usually of mangrove wood. A middle sideboard, the kapi kapi, is added above the bengkol. Again, these two boards are joined edge to edge with wooden 
dowels. Reversing Western methods of construction, the internal ribs are then fitted in place, after the main hull has been assembled.

Separating the bow and stern sections, fore and aft, from what will eventually be the living area of the lepa, a pair of large cross-beams called the sa'am are inserted and fitted into the upper sideboard, the koyang koyang, which is joined to the hull above the kapi kapi. These beams curve upward from what will be the deck of the finished boat and extend a short distance above the top of the freeboard on each side. Eventually, when the boat is fitted for use, the ends of the sa'am are drilled and fitted on each side with a rack-like branch called the panga'. From the panga', along each side of the boat are hung fish-spears, bamboo poles, and masts. Unlike the rest of the boat, the sa'am are carved from the wood of small gellom trees (Osbornia octadonata), which grow abundantly in the district along coralline shorelines and flats, just above the tidemark ${ }^{4}$, while the panga' are cut from gellom branches. The upper ends of the sa'am are frequently ornamented with carved designs produced by a skilled carver using a knife and mallet (photo 3). Typically, the lower edge of the bowsprit is also ornamented and often, as well, the forward edge of the keel (fig. 2). The principal cross-beams that reinforce the hull are inserted next. These are called sengkol. A larger beam, through the center of which passes the mast, is inserted forward from the first sengkol. This is called the patarukan. The sengkol, which are inserted after the patarukan is in place, support the deck planks and their number depends upon the length of the lepa $a^{5}$. Finally, the freeboard is extended upward on each side of the boat by adding additional boards called dinding, or "walls", which, again, are secured, edge to edge, with wooden dowels.

The midsection of the lepa is floored with fitted but removable decking (lantai), which can be taken up for bailing or for stowing fish beneath the deck. Cutting and fitting decking planks is one of the last stages in the building process. The midsection living and sleeping quarters is called the balutu or kubu and comprises roughly half of the overall length of a boat (see fig. 2). The bow (munda') and stern (buli') areas, by contrast, are low in the water and open-sided. This is to facilitate the handling of nets and the use of poles and oars.

The most durable parts of the lepa are the solid keel, bow, and stern sections. These generally last for the life of the boat. Other elements, such as the sapau roofing, require replacement every few years. During maximum ebb tides, lepa are careened and the hull is fire-treated with palm frond torches. When sideboards and other fitted sections are taken apart and reassembled, the joints are caulked or filled with the soft inner bark of the gellom tree. This bark has an oily texture that the villagers say is impervious to water. A supply of gellom bark is also carried aboard the lepa to patch leaks at sea. 


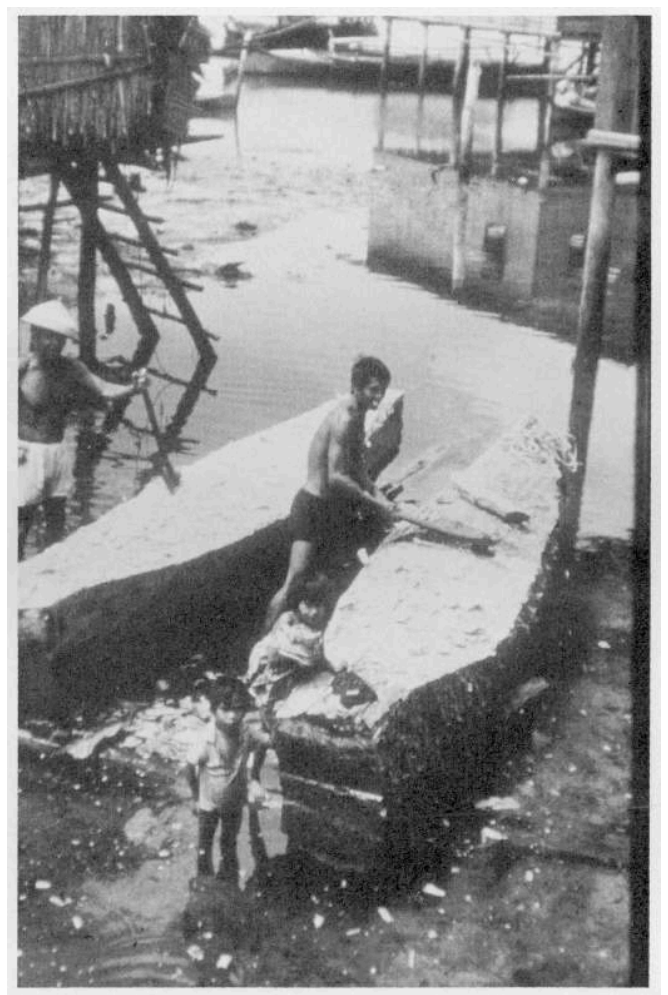

Photo 1. Shaping the keel section (teddas) of a lepa

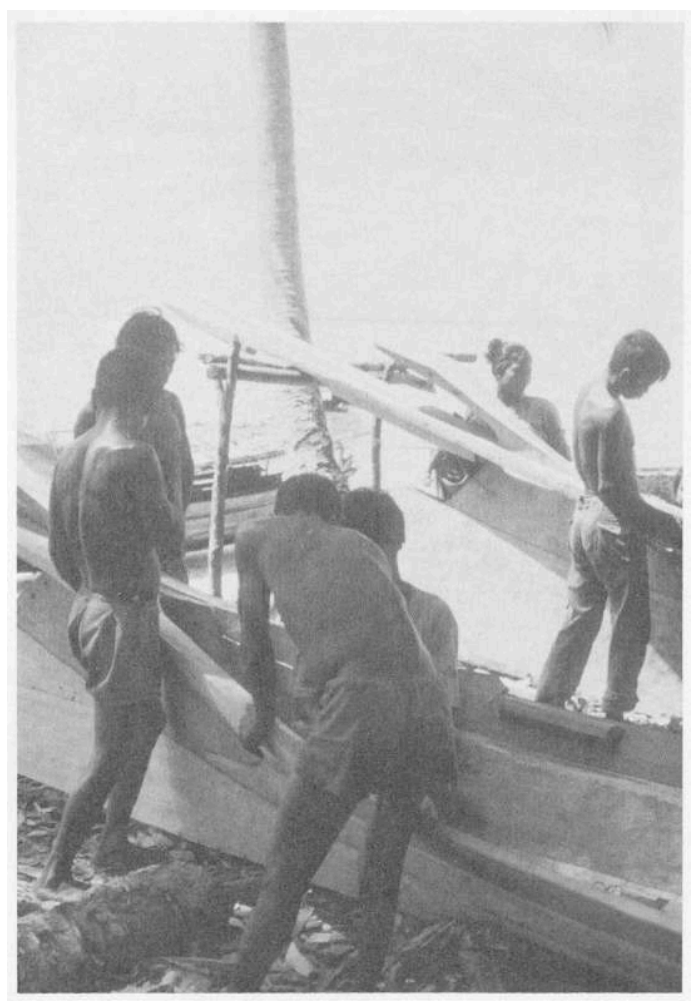

Photo 2. Assembling the hull of the lepa (1979, Semporna) 


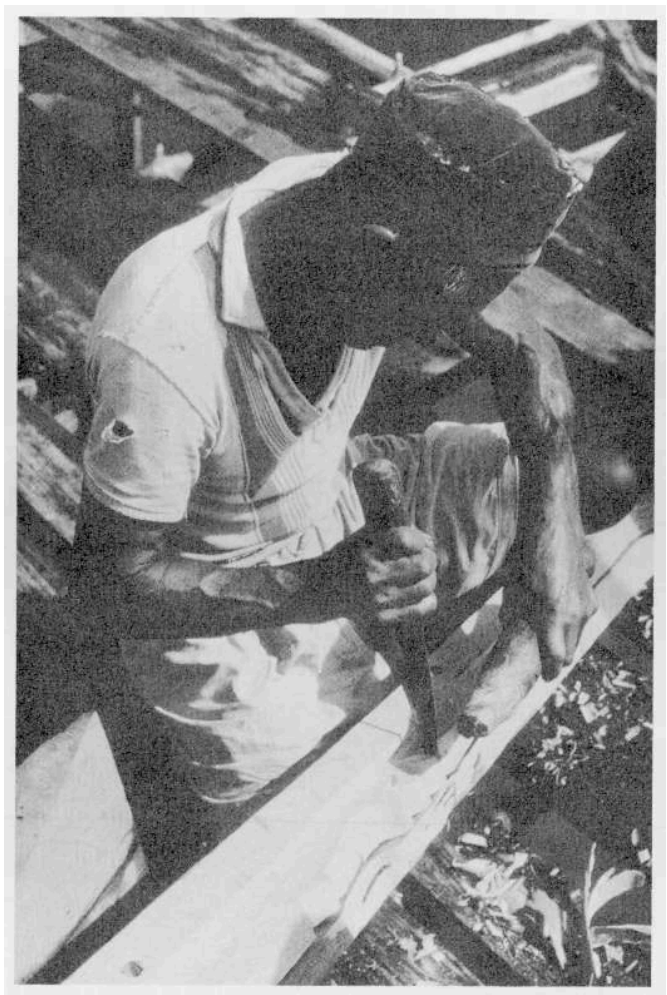

Photo 3. Carving design work on the lower side of the jungal (1965, Bangau-Bangau) 


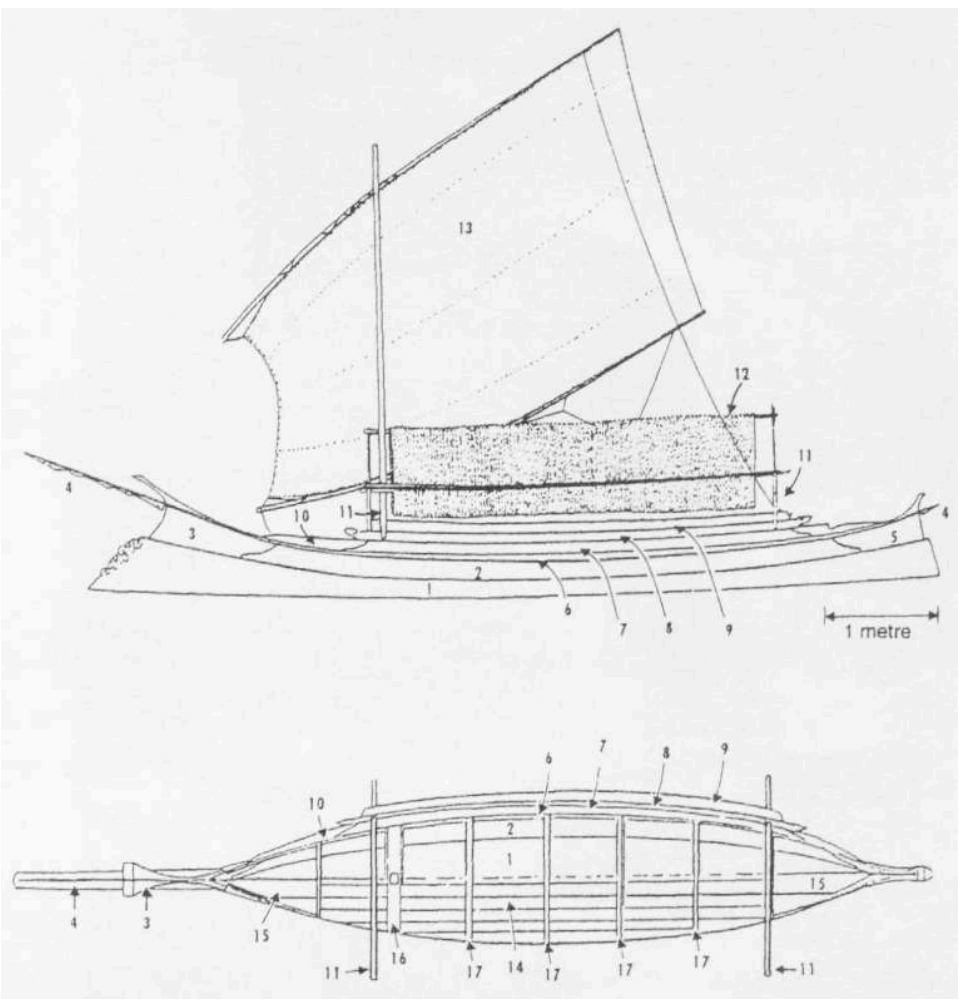

1 Teddas (keel)

2 Pangahapit (strake)

3 Tuja' (bow section with raised poling platform)

4 Jungal (side-pieces ending forward in a projecting bowsprit and aft in a small stern projection)

5 Tuja' buli' (stern section)

6 Bengkol (lower sideboard forming fitted gunwale)

7 Kapi kapi (middle sideboard)

8 Koyang koyang (upper sideboard)

9 Dinding (wall of living quarters)

10 Ajong ajong (forward side-piece)

fore and aft)

12 Sapau (roof)

13 Lamak (sail)

14 Lantai (deck planks)

15 Panansa'an (bow and stern deck)

16 Patarukan (forward cross-piece and mast support)

17 Sengkol (cross-pieces reinforcing hull and supporting deck planks)

Figure 2. Bajau Laut lepa

In 1964-65, Bajau Laut pile-houses were constructed with an attached platform used as a boat-landing stage and a drying-area for nets and fish. Platforms also served as boatbuilding areas and, when a lepa was being constructed, an awning of sails was often hung over the platform to provide shade.

More than half of the lepa in use in 1965 were said to have been purchased, while most of the remainder were built by their owners. Boats were purchased, usually under a contract arrangement, either from a village boat-builder or from a Sama Kubang boatwright. The average price of a lepa in 1965 was RM800-900 (then approximately USD270-300), with the cost of a large, finely made boat approaching RM2,000 (USD670). A growing scarcity of timber meant that, by the end of the 1960s, most wood had to be purchased from local sawmills. By 1965, even if a man built his own boat, purchased materials seldom cost less than RM400-500 (USD130-170). In terms of village incomes, boats represented a very considerable investment. 

fine design-work (ukilan) and were paid by other builders to add carved ornamentation to the bow section (tuja') and the ends of the sa'am. All three were experienced boatbuilders and house group leaders (nakura luma'). Most men, in the 1960s, had acquired a knowledge of boat construction in childhood, when they had helped their fathers to careen and care for the family lepa. Such care typically entailed the periodic disassembling of parts of the boat, and the fashioning and replacement of elements such as strakes, sideboards, and dowels. Later in life many applied this knowledge, and further experience gained by assisting others, to build boats of their own. In the beginning, a man was likely to seek the help of more experienced kinsmen, but later, having built one, or perhaps several boats, an older man was likely to be called on for advice by his younger kin, just establishing themselves as new boat owners.

who built their own boats generally did so in stages, thereby spreading the cost of materials over a period of time. Between stages, savings could be accumulated, or fishing undertaken to acquire the cash needed for the next stage of construction. Much the same principle applied to the purchase of boats. Agreements of purchase were made in the form of a promissory vow (jani') concluded between the purchaser and boatwright. Vow-taking is a major feature of Bajau Laut social and ritual relations (see Sather 1997: 287-89). In this case, the vow assumed a narrowly commercial form. According to its terms, the purchaser ordinarily advanced the builder part of the price of the boat for materials and expenses; he then made additional payments from time to time while the boat was under construction, paying the balance upon its completion.

21 All boats are individually owned. In the past, it was expected that a young man, upon marriage, would be outfitted by his family with his own lepa so that he and his wife could begin their married life as a separate fishing unit. Virtually all men remained boat owners, from the time of marriage, throughout the rest of their lives. At the death of a boat owner, the vessel was disassembled and its pieces were used to make the owner's coffin.

In addition to the lepa, in the 1960s, the Bajau Laut also made use of the smaller boggo ${ }^{6}$. The boggo' is an extremely beamy dug-out, 3-5 metres long, hollowed by means of an adze from a single tree-trunk. In profile, the bottom line and gunwale ate slightly concave. In the vicinity of the village, the boggo' is often used by young people, including adolescents and children, and was, in 1964-65, the principal means used to reach pile-houses unconnected by catwalks to the main village bridge. It is most often propelled by poling or by the use of paddles. However, a few boggo' are made with a mast socket and can be used with sails. Unlike the lepa, the boggo' generally carries only one or two persons and is used close inshore, mainly for intertidal collecting or linefishing. Occasionally, a family may tow a boggo' behind its lepa and use it at sea as a second boat to set out or haul drift nets in shallow water.

In 1964-65, lepa in the Semporna district were propelled chiefly by sail. However, at the time, 40 percent of all boat owners also owned small, newly introduced $4.5 \mathrm{hp}$ outboard engines ("Seagull» and «British Anzoni »). These were used only sparingly, however, because of the high cost and scarcity of petrol. But, by 1974, their use had become nearly universal and was beginning to effect a marked change in voyaging and marketing patterns (see Sather 1997 : 79ff).

Techniques \& Culture, 35-36 | 2001 


\section{Rituals of boat construction}

One notable feature of the preceding account of boat building is that no ritual observances accompany the construction or launching of a lepa. However, the builder or owner, might sponsor a small meal, preceded by prayers, to mark the completion of a lepa and to thank those who had assisted him. But, such meals were not mandatory and, in practice, were seldom held. Some villagers are believed to possess spells capable of causing storms to abate at sea, but otherwise there is little magic associated with either navigation or fishing. However, boats may be treated with spells (haligmun) before the owner embarks on a long journey, to render them invisible to pirates or to make them impervious to bullets (panglias). In addition, if a boat crew experiences serious difficulty at sea, the boat owner may make a pledge (magjanji') to God or the ancestors that, if they are delivered from danger, he will sponsor prayers and a feast of thanksgiving (called magmaulud or magbajanji) upon their return to the village (see Sather 1997 : 288-89). Similarly, family members at home may make a pledge if a crew fails to return when expected or is otherwise believed to be in danger.

While important symbolic meanings attach to the lepa, this general absence of ritual associated with boat construction and use appears to be widely shared by other Sama Dilaut groups in Sulu. In eastern Indonesia, the situation is different. Here, a number of recent studies have discussed boat-related ritual (e.g., Horridge 1986), including several recent ethnographies (Barnes 1996, Southon 1995). Writing on the Butonese, Southon describes a boat-building and ritual tradition that, in general outline, has come to be widely shared by a number of ethnolinguistic groups in southeastern Sulawesia, Buton, Bonerate, and in the smaller islands of the Flores Sea to the south, including, in some area, local Sama (or Bajo) speaking-groups. Recently, Stacey (1999) has described a variety of this tradition, practiced by local Bajo communities in the Tukang Besi Islands and in more recently founded offshoot communities in eastern Nusa Tenggara, including Rot :.

In this tradition, there are two main rituals associated with boat construction, one performed in conjunction with the joining of the bow and stern posts to the keel, and the other, with the drilling of the boat's «navel " (Stacey 1999: 97-105). The latter is the more crucial ritual and is described by Stacey as the most important moment in a boat's construction. Together, these two rituals liken the construction of a boat to the conception and birth of a human child (Stacey 1999 : 98). The first of these rituals -the joining of the keel to the bow and stern posts - is accompanied by offerings and prayers and ritually initiates the construction process by imparting, according to Stacey, a state of «coolness" to the vessel that is about to take form. The pieces are assembled with tenon joints, with the keel, in this case, representing the «female " part, and the stem and stern posts, the "male» parts. Their union symbolically represents sexual intercourse and the "conception » of the boat. Following this, once the main structure of the boat has been completed, a major ceremony is held in which a « navel » is drilled into the keel. This is followed, immediately afterwards, by the launching of the boat. With the drilling of the navel, typically performed by a ritual expert, the boat is given "life» (nyawa) - which is believed to reside in the navel- and vitality or life-force, so that it is animated with volition and so may seek out wealth and protect its owner. Symbolically, by means of these rituals, the boat becomes the "child» of the owner and his wife, who are thereby charged with its care (Stacey 1999: 102). For the Bajau 
Laut, while the lepa is also associated with body imagery, this association is not as explicitly formulated, and as Thomas Kiefer and I discussed (Kiefer and Sather 1970) in relation to grave markers, body symbolism, although expressly present, is culturally masked and linked more generally with gender categories and, in this instance, as we shall see, to notions of wellbeing and the ontological status of the ancestors.

\section{Internal divisions and uses of the lepa}

The symbolism of the lepa, and its association with gender, are related, in particular, to distinctions between the forward and stern sections of the boat, and with the vessel's internal orientation in terms of its lateral kokan, or « headside ». We shall look first at the way in which the lepa is used in relation to distinctions between its bow, stern, and midsections, and then take up, in the next section, the lateral orientation of the lepa and the connection of its « headside » with ideas of life, wellbeing, and relations with the ancestors.

In the Sama Dilaut dialect, munda' (or pamunda) refers to the front or projecting foresection of a boat and is used, in a general sense, as a numerical classifier when talking about boats. In addition, a nominal form, pagmunda' refers to an alliance group comprised of families that sail and moor their boats together, often tying them in tandem to a single mooring pole (soan). Down through the mid 1950s, when the Bajau Laut were still boat-living, pagmunda' or family alliance groups represented the principal social grouping, above the family level, within each anchorage community and were typically organized around a central core of married siblings, spouses, and children. In constructing the first houses in Bangau-Bangau, these pagmunda' groups formed the basis on which multi-family households and house group clusters took form (see Sather $1997: 56 \mathrm{ff}$ ). Thus, the first set of houses in Bangau-Bangau were built by the members of a pagmunda' group headed by Panglima Atani, the government-appointed leader at the time of the entire Bajau Laut community in Semporna, and as the village grew, new house group clusters were founded as other pagmunda' groups successively abandoned boat-dwelling.

The root term munda', referring to the fore-section of a boat, is contrasted with the term buli', referring to the back or stern area. The two terms may also be applied to the human body, in which case they similarly refer to the front and back side of the body. There is, however, a strong masculine nuance to the term munda'. Thus, pamunda', in a figurative sense, also refers to the penis. This same nuance applies to boats and to the pagmunda' groups which are identified by name with their senior male leaders (matto'a). Thus, the forward area of the lepa is associated, in particular, with men and male activities, while the stern is associated with women and female activities.

At the fore and aft ends of the living area, deep sockets are set in the keel of the lepa. When a boat is under sail, the forward socket receives the base of the mast. At other times, for example at night, or when family members wish to take shelter from the weather, the two sockets are fitted with shorter posts. These are forked at the top to receive a long pole-beam. Over this beam a kajang mat or sapau is spread to form a pitched roof, covering the entire midsection living area. The eaves of the roof extend just beyond the top of the freeboard on each side of the lepa and are held in place by poles and masts hung from the panga'. When not in use, the sapau is removed, rolled up and stowed out of the way, together with the shorter posts, leaving the deck free to 
serve as a family working area. While at sea, family members sleep and store their extra clothing and other personal effects in this midsection living area. The stern (buli') of the boat, by contrast, is used mainly for cooking and for stowing water jars (kibut), firewood, and food stores (lutu), principally, in the 1960s, large cakes of cassava flour wrapped in sacking or banana leaves. Here, the family's earthenware hearth is also kept. The stern is thus associated with female tasks, such as preparing meals, while the bow is reserved chiefly for fishing, poling, and for manning the sails, and for hauling and storing nets, all principally male activities. This association of the stern with women and the bow with men is carried over into death rituals. When the body of a family member is carried on its final voyage from the village to the community's cemetery, a white flag is borne from the bow of the boat in the case of a man, and from the stern in the case of a woman.

\section{Cultural meanings}

31 Although boats are constructed without overt ritual, their use is nevertheless culturally ordered, and their internal spatial divisions are oriented and express important social categories and meanings. In addition to the bow and stern, with their dichotomous body imagery of front and back, and of male and female, the midsection living area also has a lateral kokan or "headside». The kokan is the primary locus of rituals within a boat, a focus of family life and wellbeing, and the principal physical link between a family and the ancestors, including its own particular ancestors.

Conditions of personal health and wellbeing and, by the same token, sickness and death, reflect, for the Bajau Laut, the state of an individual's life-soul (sumangat), breath (napas), and of feelings and experiences associated with the body (baran). Hence, each living person has a life-soul, which, at the time of birth, is believed to attach itself inside the body. While life is believed to depend upon the conjunction of this life-soul with breath, death is described as the " cessation of breath " (abakkat napas). Prolonged absence of the life-soul from the body causes a loss of vitality, unconsciousness, and finally a cessation of breath. Thus, at death, the conjunction of these elements of personal being - body, life-soul, and breath- is ruptured. The soul takes permanent leave of the body, breathing ceases, and, unanimated by soul and breath, the body decomposes.

Each person, in addition to the life-soul, has also a transcendental soul (ruah). The transcendental soul is believed to be created by God and, once created, is said to exist forever. Moreover, it is thought to exist separately from the body, although some say that it may enter the body when a person prays. In contrast to the life-soul, the transcendental soul is associated with an individual's moral constitution; thus, a person's good and evil deeds are registered in the fate of his or her ruah. After death, the transcendental soul eventually goes to heaven (sulga'), following, for most persons, a period of punishment in hell (nalka). Once it teaches heaven, it is said «to have returned to God » (Sather 1997 : 294).

By contrast, after death, the life-soul is said to linger for a time in places frequented by its owner in life. Hence, immediately before the removal of a body for burial, the lifesoul is ritually expelled from the interior of the boat or house. Eventually, the life-soul disappears. However, if the deceased died in a state of unresolved ill-will, or if the body was improperly cleansed before burial, the deceased may reappear briefly after death 
as a "shade" or panggua'. The panggua' is, in some respects, the antithesis of the transcendental soul and is generally conceived of as a shadowy manifestation of the corporal body, sometimes momentarily appearing to the living as a rotting corpse. Although not always visible, the presence of a panggua' is announced by an odor of corruption or decay. Sometimes at night, a sudden wind may blow through the village, or through a mooring where boats are anchored, bringing with it an odor of decay. This may be attributed to the passage of a company of panggua'. Dark nights, when the moon is late in rising, are associated, in particular, with the visits of traveling shades. At such times, people are likely to remain inside their boats, or in their houses, where they keep a light burning and seal off the entrances (Sather 1997 : 315).

Physically, the headside forms the main ritual orientation of a boat, and, today, by extension, of the Bajau Laut house. The kokan is closely associated with health and the wellbeing of family members. Thus, the sick are laid, with their head at the kokan, and are treated there by spirit-mediums. Here, too, at the kokan, mediums invoke and converse with the ancestors, and at times enlist their intercession on behalf of the ailing family member. During weddings, the bride sits facing the kokan, with her back to the gathered families, and at the climax of the ceremony she is turned by the groom to face outward, after which the couple sit with their backs to the kokan. While at sea, during the day, family members store their personal effects at the kokan and, at night, they lay their heads ( $k o k)$, when sleeping, at the kokan side of the boat, with their bodies oriented crossways, perpendicular to the fore and aft sections of the vessel. For a pregnant woman it is especially important that she observe this kokan orientation, or otherwise, it is believed, she may disorient the infant in her womb and so cause a breach delivery. Graves, too, have a headside which is marked by a grave marker placed directly over the head of the buried body. The marker is an iconic replica of the body (see Kiefer and Sather 1970), and when the imam pronounces the final prayer for the dead, he addresses his words to the marker at the headside of the grave. Here, too, descendants place remembrances to the ancestors or mbo' (Sather $1997: 285$ ).

Perhaps, most significantly, the kokan symbolizes the life of family members. Thus, at death, an imam or prayer leader is called. His first act is to turn the body of the dead person so that its head no longer points toward the headside of the boat (or house). This simple act of reorientation, positioning the head and feet of the body perpendicular to the "headside", so that they are now in line with the bow and stern, signifies death and the departure of the deceased's life-soul from the living world in which the boat serves as a prime source of orientation. In Sama, the body, at this point, is no longer described as a "body" (baran), but is now referred to as a "corpse" (bangkai). Only a corpse (bangkai) may lay lengthwise in a boat, with its head toward the bow and its feet toward the stern, and it is in this orientation that the corpse is transported to the cemetery for burial.

The principal association of the kokan is with the ancestors. According to Bajau Laut myths, in the beginning, there existed only eternal beings : God (Tuhan) and the spirits (saitan). God then created the first ancestors (mbo'). After creating the mbo', Tuhan informed the first ancestors that they would have to die, but that they could choose the form their death would take. He offered them two alternatives. They could die like the moon (bulan) and be repeatedly reborn, or they could die like the banana plant (saging), whose main stalk dies, but is replaced by new shoots. The ancestors chose the latter death. Hence, present-day people, those «descended from» (turunan) the first 
ancestors, die, never to be reborn again. They bear children, however, who, like the banana shoots, take their place in the physical world (Sather $1997: 18$ ). Although the ancestors are not eternal beings like Tuhan and the spirits, they nonetheless exist both in and out of time. In choosing not to die like the moon, the mbo' rendered human life, from then onward, non-cyclical (Bottignolo 1995 : 25-28). At death, for each individual, mundane existence ends forever. The individual departs from the earthly world, never to return again, and in this world his or her place is taken by others who are similarly fated to die in time. However, in death, an aspect of each individual's being (which some identify with the ruah) is thought to be transformed, and he or she becomes mbo', and so, as an ancestor, escapes the historical present -the contingent time of birth and death - and enters a dimension shared with the first ancestors. Although invisible, the ancestors become transcendent beings and so remain immediately present and forever accessible to their living descendants, in whom they are believed to take a continuing interest.

The ancestors thus remain of central importance to the Bajau Laut and are frequently appealed to for assistance or protection (see Sather 1997: 313ff). Above all, for the Bajau Laut, the ancestors are associated with the sea. Thus, in going to sea, a family enters, as it were, the domain of the ancestors. With coming and going a regular feature of Bajau Laut life, expressions of remembrance (magentom-entoman) are highly valued socially and are seen as giving meaning, in emotional terms, to the recurrent experiences of departures and reunions. Often, personal objects, as tokens of remembrance (pagentoman) are requested, or exchanged between loved ones, as reminders of their feelings towards one another. In relation to the ancestors, the villagers say that death, in this case, is only a temporary parting, such as are constantly experienced in everyday life. The living must therefore continue to remember the dead (entom ma siga'), as a sign of their enduring love, until the time arrives when they are both reunited as mbo' (see Sather 1997 : 319).

While emotions have their source in the atai (or « heart»), and so are identified with bodily experience ; intelligence, moral judgment, and restraint all have their seat in the " head " (kok). Hence, the special importance attributed to the head by the Bajau Laut. The head is also associated with the elders (matto'a) and the ancestors (mbo'), and particularly, as we have just seen, with the headside orientation of boats, houses, and graves. Like the head, the ancestors are a source of moral restraint. In this sense, they constitute a kind of collective "head", serving society as a whole as an enduring reservoir of moral authority, both immediate and yet existing forever.

\section{Changes in boat design and disappearance of the lepa}

In 1979, although lepa were still occasionally built, they were rapidly being replaced at the time as the main fishing boat by the pombot, a plank-constructed vessel powered by a small inboard engine of 10-16 hp. Without the lepa's solid keel, bow and stern sections, the pombot was much cheaper to build, requiring much less timber, and its inboard engine was far more dependable and efficient. Moreover, in the years that followed, the pombot proved to be a highly adaptable vessel and has since undergone a proliferation of design modifications fitting it to a variety of different uses, from fishing to ferrying passengers. In 1994, the last time I returned to Bangau-Bangau, the 
villagers had completely ceased building lepa and these elegant boats, once so inseparably identified with the Bajau Laut, were now only a fading memory.

\section{BIBLIOGRAPHY}

Barnes, Robert H., 1996, Sea Hunters of Indonesia. Fishers and Weavers of Lamalera. Oxford :

Clarendon Press.

Bottignolo, Bruno., 1995, Celebrations with the Sun: An Overview of Religious Phenomena among the Badjaos. Quezon City : Ateneo de Manila University Press.

Burningham, Nick, 1989, « Four double-ended perahu lambo », The Beagle, Records of the Northern Territory Museum of Arts and Sciences 6 (1): 179-93.

- 1992, « Bajau lepa and sope : 'A seven-part canoe' building tradition in Indonesia », The Beagle, Records of the Northern Territory Museum of Arts and Sciences 10 (1): 193-222.

Cook, Oscar, 1924, Borneo : The Stealer of Hearts. New York : Houghton Mifflin. Horridge, Adrian - 1986, « A summary of Indonesian canoe and perahu ceremonies », Indonesia Circle 39 : 3-17.

Kiefer, Thomas M., 1972, The Tausug : Violence and Law in a Philippine Moslem Society. New York : Holt, Rinehart \& Winston.

Kiefer, Thomas and Clifford Sather, 1970, « Gravemarkers and the repression of sexual symbolism : the case of two Philippine-Borneo Moslem Societies ", Bijdragen Tot de Taal-, Land- en Volkenkunde 126 : 75-90.

Kurais, Muhammad, 1975, « Boatbuilding of the Sama », Mindanao Journal 1 (4): 67-125.

Malaysia, Department of Statistics, 1993, Siaran Perangkaan Bulanan, Sabah [Monthly Statistical Report, Sabah]. Kota Kinabalu : Jabatan Perangkaan Malaysia, Cawangan Sabah.

Nimmo, H. Arlo, 1990, " The boats of the Tawi-Tawi Bajau, Sulu archipelago, Philippines », Asian perspectives 29 (1): 51-88.

Sather, Clifford, 1978, "The Bajau Laut », pp. 172-92, in V.T. King (ed.), Essays on Borneo Societies. Oxford : Oxford University Press (Hull Monographs on South-East Asia, ${ }^{\circ} 7$ ).

- 1985, « Boat Crews and Fishing Fleets : the social organisation of maritime labour among the Bajau Laut of Southeastern Sabah », Contribution to Southeast Asian Ethnography $4: 165-214$.

- 1993, « Bajau », pp. 30-35, in David Levinson (ed.), Encyclopedia of World Cultures, Vol. 5, East and Southeast Asia. Boston : G.K. Hall and Co.

- 1997, The Bajau Laut : Adaptaton, History, and Fate in a Maritime Fishing Society of South-Eastern Sabah. New York/Kuala Lumpur : Oxford University Press.

Southon, Michael, 1995, The Navel of the Perahu : Meaning and Values in the Maritime Trading Economy of a Butonese Village. Canberra : The Australian National University (Research School of Pacific and Asian Studies). Spoehr, Alexander

- 1971, The Double Outrigger Canoe of Zamboanga and the Sulu Archipelago, Southern Philippines.

Honolulu : Occasional Papers of Bernice P. Bishop Museum, 24, 7. 
Stacey, Natasha, 1999, Boats to Burn : Bajo fishing activity in the Australian fishing zone. Unpublished PhD dissertation. Darwin : Northern Territory University.

Walton, Janice and Moody David, 1984, « East Coast Bajau Languages », pp. 113-22, in J. King and J. King (eds), Languages of Sabah : A Survey Report. Canberra : The Australian National University (Pacific Linguistics, Series $C, \mathrm{~N}^{\circ} 78$ ).

\section{NOTES}

2. Sapau are plaited from the fronds of a coastal palm (unidentified) known as tigul in Sama (see Sather 1997 : 32-33).

3. For further details concerning the construction of the lepa see also Martenot (this volume) and Burningham (1992: 200-2) and for a discussion of the more typical double and single outrigger vessels built and used by Bajau-Sama populations in the Sulu Archipelago, see Spoehr (1971). Kurais (1975) and Nimmo (1990) provide excellent accounts of the different types of Sama boats used in the Sulu Archipelago. Burningham $(1989,1992)$ and Stacey (1999) provide a similar discussion of Bajau (or Bajo) boats in southeastern Sulawesi and eastern Nusa Tenggara, Indonesia. Testifying to the remarkable adaptability of these seafaring people, interestingly, the main craft in this latter region, the perabu lambo, exhibits design elements apparently derived from small European fore-and-aft rigged vessels, possibly small XIXth century sloops or cutters, making it, in terms of design, the most westernized of all indigenously-built Indonesian boats (cf. Burningham 1989 : 179)

4. This type of environment is called lakit in Sama. Gellom occasionally grow into medium-sized trees, although they are more familiar as shrubs. When available, these larger trees are favored as house piles.

5. By analogy, double, or multiple marriages, arranged between couples from two sibling sets, which are similarly intended to reinforce ties between their families, are called magtumbuk sengkol unions (Sather 1997 : 266-68).

6. Unfortunately, at the time, I failed to made a complete census of boggo' and boggo' ownership, but they were somewhat fewer in number than the lepa.

\section{ABSTRACTS}

Until the mid 1950s, the Bajau Laut of the Semporna district, Sabah, lived entirely on boats. These boats, called lepa, served both as a family's living quarter and as its principal productive asset. Until recently boat-building timber was comparatively plentiful in Semporna, with the result that not only did the Bajau Laut build boats for themselves, but they, and neighboring shoredwelling Sama-speakers, also built lepa for trade. It seems probable, indeed, that the design of the lepa originated with local shore-living boatwrights. This paper describes the process involved in building a lepa, the use of boats, their internal features, and the association of these features with social categories and ideas relating in particular to the ancestors $(\mathrm{mbo})$. The paper also discusses briefly changes in boat design that have occurred as the Bajau Laut have ceased to be full-time boat-dwellers and as the coastal lowlands have been deforested as a result of recent commercial logging. 
Jusqu'au milieu des années cinquante, les Bajau Laut du district de Semporna (Sabah) vivaient complètement sur leurs bateaux. Ces derniers, appelés lepa étaient à la fois un espace de vie familial et le principal moyen de production. Récemment encore, le bois d'oeuvre nécessaire à la construction navale était abondant à Semporna. Les Bajau Laut pouvaient donc construire des lepa pour eux-mêmes, mais aussi, avec l'aide de leurs voisins du littoral (de langue sama), à des fins commerciales. Il est probable cependant que l'origine du lepa soit le fait des constructeurs du littoral. Cet article décrit les processus de fabrication, les différents usages des lepa, leur structure interne et les liens que l'on peut établir avec les catégories sociales, en relation, en particulier avec les ancêtres (mbo'). Seront également brièvement examinés les récents changements apparus dans la forme des bateaux depuis que les Bajau-Laut ont cessé de vivre sur l'eau, et depuis la déforestation dûe à l'exploitation commerciale.

Hasta mediados de los años cincuenta, los Bajau Laut del districto de Semporna (Sabah) vivían permanentemente en sus barcos. Estos últimos, llamados lepa, eran a la vez un espacio de vida familiar y el principal medio de producción. Todavía recientemente, la madera necesaria para la construcción naval era abundante en Semporna. Los Bajau Laut podían pues construir sus lepa para ellos mismos y también con la ayuda de sus vecinos del litoral (de lengua sama), para fines comerciales. Sin embargo es probable que el origen del lepa provenga de los constructores del litoral. Este artículo describe los procesos de fabricación, las diferentes utilizaciones de los lepa, su estructura interna y las relaciones que pueden establecerse con las categorías sociales, en relación, en particular, con los ancestros ( $m b o$ ). Serán igualmente examinados brevemente los cambios aparecidos en la forma de los barcos desde que los Bajau Laut han dejado de vivir sobre el agua, y desde la deforestación, desbida a la reciente explotación comercial.

\section{INDEX}

Mots-clés: architecture navale, Bajau Laut, littoral, Malaisie, nomades, Sama, Semporna

\section{AUTHOR \\ CLIFFORD SATHER}

Institute of Anthropology, University of Helsinki, Finland 